\title{
The Effect of the Modified Thoracolumbar Interfacial Nerve Plane Block on Postoperative Analgesia and Healing Quality in Patients Undergoing Lumbar Disk Surgery: A Prospective, Randomized Study
}

\author{
Lomber Disk Hernisi Cerrahisi Olan Hastalarda Modifiye Torakolumbar \\ Interfasial Sinir Plan Bloğunun Postoperatif Analjezi ve İyileşme Kalitesine \\ Etkisi: Prospektif, Randomize Çalışma
}

\author{
Ozgur OZMEN $\odot$, Ilker INCE $\odot$, Mehmet AKSOY $\bullet$, Aysenur DOSTBIL $\odot$, Canan ATALAY $\odot$ \\ Kamber KASALI ๑
}

Ethics Committee Approval: This study approved by the Ataturk University, Clinical Studies Ethic Committee, 30 May 2019, 2019/475.

Conflict of interest: The authors declare that they have no conflict of interest.

Funding: None.

Informed Consent: Informed consent was taken from the patients enrolled in this study.

Cite as: Ozmen O, Ince I, Aksoy M, Dostbil A, Atalay C, Kasali K. The effect of the modiquality in patients undergoing lumbar disk surgery: A prospective, randomized study. Medeniyet Med J. 2019;34:340-5.

\begin{abstract}
Objective: The purpose of this study was to investigate the effect of the modified thoracolumbar interfascial plane block (TLIP) on postoperative analgesia and quality of recovery in patients undergoing lumbar disk surgery.

Method: Ninety patients scheduled for lumbar disk surgery were divided into a control group (Group C) and a modified TLIP block group (Group T). Controlled analgesia was administered to both groups. Pain evaluation was performed at 30 min and at 1., 2., 4., 8.,12., and 24. hrs using a VAS scale, with patients at rest and duringand patients completed the QoR-40 quality of recovery inventory.

Results: Fentanyl used during postoperative 24 hours was $742.5 \pm 220.3 \mathrm{mcg}$ in Group Cand 446.0 \pm 241.98 in Group T. Postoperative fentanyl consumption was statistically significantly lower in Group $T(p<0.001)$ with a statistically significant intergroup difference. The patient's pain, physical independence, physical comfort, psychological support, and emotional support were compared using the QoR-40 questionnaire survey. Significant differences in favor of Group T were observed $(p<0.001, p=0.017, p=0.002, p=0.001$ and $p<0.001$, respectively). Static and dynamic pain scores in Group C and Group T were recorded at 30 min and at 1, 2, 4, 8, 12, and $24^{h}$. Mean static scores were statistically significantly different in favor of Group $T$ with the exception of $8^{\text {th }}$ and $12^{\text {h }}$ assessments $(p<0.05)$. Dynamic scores were statistically significantly different in favor of Group $T$ at all time points $(p<0.05)$.

Conclusion: Pain scores, opioid consumption and $Q o R-40$ values after lumbar disk surgery were superior in the group undergoing TLIP. We think that the modified TLIP block may be an important method in terms of postoperative analgesia and patient recovery for lumbar spinal disk surgery.
\end{abstract}

Keywords: Fentanyl, nerve block, postoperative pain

öz

Amaç: Çalısmamızda lomber disk cerrahisinde yapılan modifiye TLIP bloğunun postoperatif analjezi ve derlenme kalitesi üzerine etkinliğini araștırmayı amaçladık.

Yöntem: Lomber Disk Hernisi cerrahisi planlanan 90 hasta kontrol grubu (Grup C) ve modifiye TLIP bloğu yapılan (Grup T) olarak iki gruba ayrıldı. Her iki gruba hasta kontrollü analjezi yapıldı. Ağrı değerlendirilmesi 30. dk. ve 1., 2., 4., 8., 12., 24. saatlerde VAS skalasılyla hastalar dinlenirken ve hareket halindeyken yapıldı. Postoperatif 24. saatte kullanılan fentanil kaydedildi, hastalara QoR-40 derlenme kalitesi anketi doldurtuldu.

Bulgular: Postoperatif 24 saatlik tüketilen fentanil Grup C'de 742,5 $\pm 220,3$ mcg, Grup T'de 446,0 241,98 mcg idi. Gruplar arasında postoperatif tüketilen fentanil miktarı Grup T'de daha azdı ve istatistiksel olarak anlamlı fark vardı $(p<0,001)$. QoR-40 derlenme kalitesi anketinde hastanın ağrı, fiziki bağımsızlığı, fiziksel konforu, psikolojik desteği ve emosyonel durumu karşılaştırıldı. Grup T lehine istatistiksel olarak anlamlı fark vardı (sırasılla $p<0,001, p=0,017, p=0,002, p=0,001, p<0,001$ ). Grup $C$ ve Grup T'de ağrı skorları cerrahi sonrası 30. dk. ve 1., 2., 4., 8., 12., 24. saatte statik ve dinamik olarak kaydedildi. Statik durum ortalama skorlarında 8. ve 12. saat haricinde Grup T lehine istatistiksel olarak anlamlı fark vardı $(p<0,05)$. Dinamik skorlarda tüm saatlerde Grup T lehine istatistiksel olarak anlamlı fark vardı $(p<0,05)$.

Sonuç: TLiP blok yapılan grupta lumbar disk cerrahisi sonrası ağrı skorları, opioid tüketimi ve QoR-40 değerleri daha etkin olarak tespit edilmiştir Lomber spinal disk cerrahisi için modifiye TLIP bloğunun postoperatif analjezide ve hasta derlenmesinde önemli bir yöntem olabileceğini düşünüyoruz.

Anahtar kelimeler: Fentanil, postoperatif ağrı, sinir bloğu
Received: 12 November 2019

Accepted: 4 December 2019

Online First: 26 December 2019

Corresponding Author: O. Ozmen ORCID: 0000-0003-2014-0468 Ataturk University, School of Medicine, Department of Anaesthesiology and Reanimation, Erzurum, Turkey dr.ozgurozmen@yahoo.com.tr

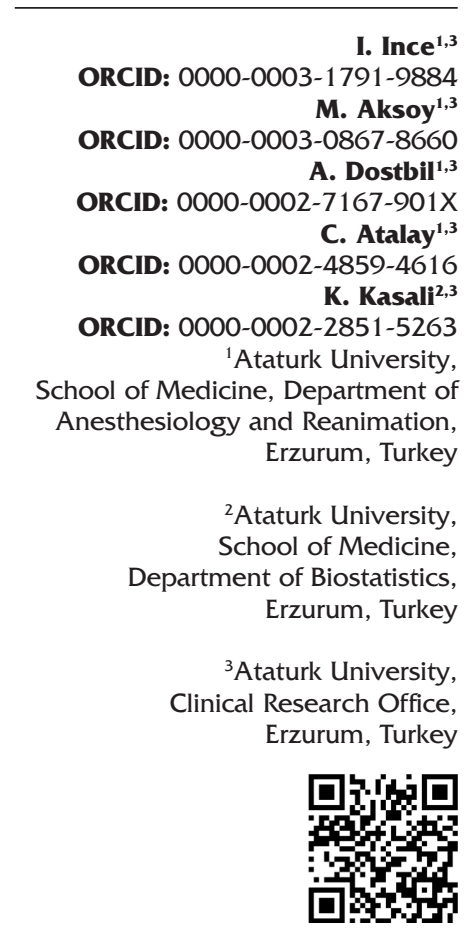


O. Ozmen et al. The Effect of the Modified Thoracolumbar Interfacial Nerve Plane Block on Postoperative Analgesia and Healing Quality in Patients Undergoing Lumbar Disk Surgery: A Prospective, Randomized Study

\section{INTRODUCTION}

Spinal surgery is characterized by diffuse and severe postoperative pain ${ }^{1}$. Various pharmacological options are available for the effective prevention of pain following spinal surgery. Protocols for reducing pain after lumbar surgery recommend the use of regional anesthesia techniques to reduce opioid analgesic use to a minimum ${ }^{2}$. Interfascial plane blocks have the potential to provide extended postoperative analgesia and to reduce opioid consumption, and neuroaxial and plexus block-related motor block to a minimum ${ }^{3}$. The thoracolumbar interfascial plane (TLIP) block was first described by Hand et al., ${ }^{4}$ which is an interfascial plane block applied at the L3 vertebral level in spinal surgery. In the TLIP, the block needle is advanced in a lateromedial orientation, with a local anesthetic agent being administered between the multifidus and longissimus dorsi muscles. The modified TLIP block has been described as a method of reducing the risk of neuroaxial nerve injury which is easier to apply than the first LIP block described $^{5}$. In the modified TLIP block the needle is advanced in a mediolateral orientation with a local anesthetic being administered between the longissimus and iliocostal muscles.

QoR-40 (Quality of recovery) is a five-dimension, 40-question inventory developed by P.S Myles that evaluates the patient's emotional state, physical comfort, psychological support, physical independence, and pain status. It was developed for the purpose of assessing quality of recovery after anesthesia and patients' health status in the early postoperative period ${ }^{6}$. The minimum possible score is 40 and the maximum possible score is 200 points. Application of the inventory does not require any special training. The fact that it can be self-administered by the patient within a short time represents a significant advantage. Karaman et al. confirmed the reliability, validity, and sensitivity of the Turkish adaptation of QoR-407.

The purpose of this study was to investigate the effect of patient-controlled analgesia together with the modified TLIP block on postoperative quality of recovery in patients undergoing singlelevel lumbar disk surgery.

\section{MATERIAL and METHODS}

This study approved by the Ataturk University, Clinical Studies Ethics Committee, on May 30, 2019, 2019/475. Informed consent was obtained from the patients enrolled in this study.

Ninety patients aged 18-60 years evaluated according to American Society of Anesthesiologists (ASA) Class I-II physical status at preoperative assessment and scheduled for elective single level herniated lumbar disk surgery between June and September 2019 were included in the study. Morbidly obese patients (body mass index $>35 \mathrm{~kg}$ / $\mathrm{m}^{2}$ ), patients with hypersensitivity to local anesthetics, nonsteroidal anti-inflammatory drugs, and opioids or allergic to anesthetic agents, cases having contraindication for TLIP block, with infection at or around the block entry site, coagulation abnormality, known hepatic, renal, or hematological disease, peptic ulcer, gastrointestinal bleeding, allergy, history of chronic pain, individuals who use analgesics routinely or within the previous $24 \mathrm{~h}$, or refuse to take part in the study were excluded.

The study population was randomized into two groups of 45 patients each by using computer software. Patients were brought into the block room, where electrocardiogram (EKG), heart rate (HR) and oxygen saturation were monitored. Venous access was established through an $18 \mathrm{G}$ cannula inserted into the left forearm. Intravenous (iv) premedication was performed with 0.025 $\mathrm{mg} / \mathrm{kg}$ midazolam, with all patients in the prone position. The region where the block was to be applied was sterilized and protected with a sterile cover. Patients in the control group (Group C), received bilateral ultrasound-guided injection of a total amount of sterile $6 \mathrm{~mL} 0.9 \%$ saline solution delivered through the L3 level between the 
longissimus and iliocostal muscles. Patients in the modified TLIP block group (Group T) received bilateral ultrasound-guided injection of $20 \mathrm{~mL}$ bupivacaine up to a total of $40 \mathrm{ML}$ delivered through L3 level between the longissimus and iliocostal muscles. A loss of cold sensation on the L1-L5 dermatomes 20 min after application was regarded as procedural success. Patients whose block procedures were unsuccessful were excluded from the study. Block procedures in both groups were performed by the same independent anesthesiologist.

Standard general anesthesia was applied to all patients. Propofol ( $2 \mathrm{mg} / \mathrm{kg})$, fentanyl $(2 \mathrm{mg} / \mathrm{kg})$ and rocuronium $(0.6 \mathrm{mg} / \mathrm{kg})$ were employed in anesthesia induction, while maintenance anesthesia was provided with mixture of 1-2\% sevoflurane and a $50 \% \mathrm{~N}_{2} \mathrm{O} / \mathrm{O}_{2}$. Thirty minutes before the end of the surgery, all patients received intravenous $50 \mathrm{mg}$ dexketoprofen trometamol (Arveles amp. $50 \mathrm{mg} / 2 \mathrm{ml}$ ) in $100 \mathrm{cc} 0.9 \% \mathrm{NaCl}$ infused over 10 min. Patient-controlled analgesia (PCA) with fentanyl was used by patients in both groups. PCA was programmed as a $25 \mu \mathrm{g}$ bolus and 15min lockout time with no basal infusion and was maintained for $24 \mathrm{hrs}$. A repeat dose of iv $50 \mathrm{mg}$ dexketoprofen trometamol (Arveles amp. 50 $\mathrm{mg} / 2 \mathrm{ml}$ ) in $100 \mathrm{cc} 0.9 \% \mathrm{NaCl}$ was administered at postoperative 12 hours.

Postoperative follow-up and evaluation was performed by a researcher blinded to the study groups. Patients with visual analogue scale (VAS) scores of 4 or more in the recovery room and at follow-ups on the ward received $1 \mathrm{mg} / \mathrm{kg}$ tramadol for escape analgesia, and these patients were recorded. Postsurgical pain evaluation was performed using a VAS scale ( $0=$ no pain, $10=$ worst possible pain) at $30 \mathrm{~min}$ and 1., 2., 4., 8., 12., and 24. hrs. VAS evaluation was performed with patients at rest (static) and in motion (raising the lower extremity). Postoperative nausea and vomiting (none, nausea only, or nausea+vomiting) were recorded. Patients with postoperative nausea or vomiting were given $10 \mathrm{mg}$ iv metoclopramide. Patients' age, sex, height, weight, and smoking status were recorded. Operative time was recorded, together with total fentanyl consumption at the end of 24 hrs. Patients were asked to complete the QoR-40 quality of recovery inventory. Patients were asked whether or not they were satisfied, and their responses were recorded.

\section{Statistical Analysis}

Analyses were performed using IBM SPSS 20 statistical software. Data were expressed as mean, standard deviation, median, minimum, maximum, percentage, and numerical values. Normality of distribution of continuous variables was assessed using the Shapiro-Wilk test. The independent samples-t test was used to compare two independent groups in case of normal distribution, and the Mann Whitney $U$ test when normal distribution was not established. For categorical variables in $2 \times 2$ contingency tables, we used the Pearson chi-square test when the predicted value was $>5$, the chi-square Yates test when the predicted value was 3-5, and Fisher's Exact test when the predicted value was $<3$. P values $<0.05$ were regarded as statistically significant.

\section{Power analysis}

We calculated that 78 patients, 39 in each groups, would be required for a $126 \mathrm{mcg}$ difference in fentanyl consumption to be statistically significant at $80 \%$ power and a $95 \%$ confidence interval when mean fentanyl consumption was $415 \pm 231$ mcg in the control group and $289 \pm 154 \mathrm{mcg}$ in the modified TLIP group ${ }^{8}$.

\section{RESULTS}

Ninety patients were included in the study. From Group C, two patients refusing to take part, three meeting the exclusion criteria and from Group $\mathrm{T}$ one refusing to take part, two meeting the exclusion criteria, and two with unsuccessful blocks were excluded, and 80 patients were finally enrolled in the study. 
No statistically significant differences were observed between the two groups in terms of age, sex, weight, operative time, ASA, or smoking status $(p>0.05)$ (Table 1$)$.

Table 1. Study group demographic data.

\begin{tabular}{llll}
\hline & $\begin{array}{l}\text { Group C } \\
(\mathbf{n = 4 0 )}\end{array}$ & $\begin{array}{l}\text { Group T } \\
(\mathbf{n = 4 0 )}\end{array}$ & p value \\
\hline Gender (F/M) & $18 / 22$ & $19 / 21$ & 0.823 \\
Age (year) & $44.63 \pm 8.48$ & $43.98 \pm 10.85$ & 0.743 \\
Height (cm) & $169.25 \pm 9.88$ & $168.15 \pm 8.88$ & 0.644 \\
Weight (kg) & $75.45 \pm 10.5$ & $75.48 \pm 10.47$ & 0.962 \\
Operative time (min.) & $75.75 \pm 13.42$ & $77.75 \pm 15.44$ & 0.603 \\
ASA (I/II) & $32 / 8$ & $33 / 7$ & 0.775 \\
Smokers (n) & 18 & 19 & 0.823 \\
& & & \\
\hline
\end{tabular}

Group C: Control group, Group T: TLIP block group.

Postoperative 24-hour fentanyl consumption was $742.5 \pm 220.3 \mathrm{mcg}$ in Group C, which was significantly lower $(446.0 \pm 241.98 \mathrm{mcg})$ in Group $\mathrm{T}$ $(p<0.001)$. Nineteen patients in Group $C$ and six in Group $T$ received escape analgesia, with a statistically significant intergroup difference $(p=0.002)$. Twenty-six patients in Group C and 36 in Group $T$ expressed satisfaction, and the difference between the two groups was statistically significant

Table 2. Postoperative analgesic consumption and patient satisfaction.

\begin{tabular}{llll}
\hline & $\begin{array}{l}\text { Group C } \\
(\mathbf{n}=\mathbf{4 0})\end{array}$ & $\begin{array}{l}\text { Group T } \\
(\mathbf{n = 4 0 )}\end{array}$ & p value \\
\hline $\begin{array}{l}\text { Total PCA fentanyl } \\
\text { dose (mcg) }\end{array}$ & $742.5 \pm 220.3$ & $446.0 \pm 241.98<0.001^{* *}$ \\
$\begin{array}{l}\text { Analgesia leak } \\
\text { (yes/no) }\end{array}$ & $19 / 21$ & $6 / 34$ & $0.002^{* *}$ \\
PONV & & & \\
None & 16 & 22 & 0.275 \\
Nausea & 14 & 8 & \\
$\begin{array}{l}\text { Nausea+Vomiting } \\
\text { Patient satisfaction }\end{array}$ & 10 & 10 & $0.025^{*}$ \\
$\begin{array}{l}\text { (Satisfied/ } \\
\text { Dissatisfied) }\end{array}$ & & $36 / 4$ & \\
\hline
\end{tabular}

Group C: Control group, Group T: TLIP block group.

*Statistically significant difference $(p<0.05),{ }^{* *}$ Highly significant $(p<0.01)$. $(p=0.025)$. Although the number of patients with postoperative nausea and vomiting was higher in Group C than in Group T, the difference between the groups was not statistically significant $(p=0.275)$ (Table 2$)$.

The QoR-40 quality of recovery inventory results were also subjected to analysis. Recovery was evaluated under five main headings as pain, physical independence, physical comfort, psychological support, and emotional state. Postanesthetic quality of recovery and early postoperative health status were significantly superior in Group T ( $p<0.001, p=0.017, p=0.002, p=0.001$, and $p<0.001$, respectively) (Table 3 ).

Table 3. Study group QoT-40 scores.

\begin{tabular}{llll}
\hline & $\begin{array}{l}\text { Group C } \\
(\mathbf{n}=\mathbf{4 0})\end{array}$ & $\begin{array}{l}\text { Group T } \\
(\mathbf{n = 4 0 )}\end{array}$ & p value \\
\hline Pain & $30 \pm 3$ & $33 \pm 2$ & $<0.001^{* *}$ \\
Physical independence & $24 \pm 1$ & $25 \pm 1$ & $0.017^{*}$ \\
Physical comfort & $54 \pm 4$ & $57 \pm 3$ & $0.002^{* *}$ \\
Psychological support & $32 \pm 1$ & $33 \pm 2$ & $0.001^{* *}$ \\
Emotional state & $41 \pm 3$ & $43 \pm 2$ & $<0.001^{* *}$
\end{tabular}

Group C: Control group, Group T: TLIP block group.

${ }^{*}$ Statistically significant difference $(p<0.05),{ }^{*} H i g h l y$ significant $(p<0.01)$.

Mean static and dynamic pain scores were recorded at $30 \mathrm{~min}$, and at 1., 2., 4., 8., 12., and

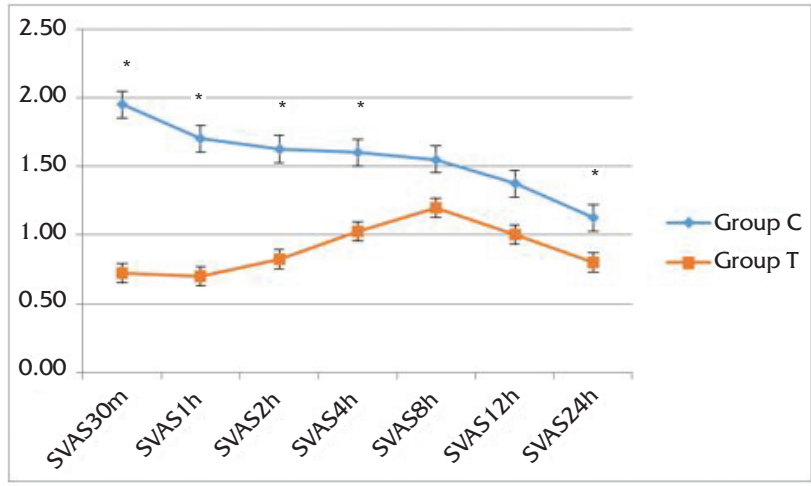

SVAS: Static visual analog scale, Group C: General anesthesia Group T: General anesthesia + Thoracolumbar interfascial plane block

*Statistically significant difference $(p<0.05)$.

Figure 1. Static visual analog scale scores over $24 \mathrm{~h}$ after surgery. 
24. hrs after surgery. Mean static pain scores were significantly in favor of Group $T(p<0.05)$, apart from at 8 and $12 \mathrm{~h}$-measurements (Figure 1). Mean dynamic pain scores were significantly in favor of Group $T$ at all time intervals $(p<0.05)$ (Figure 2).

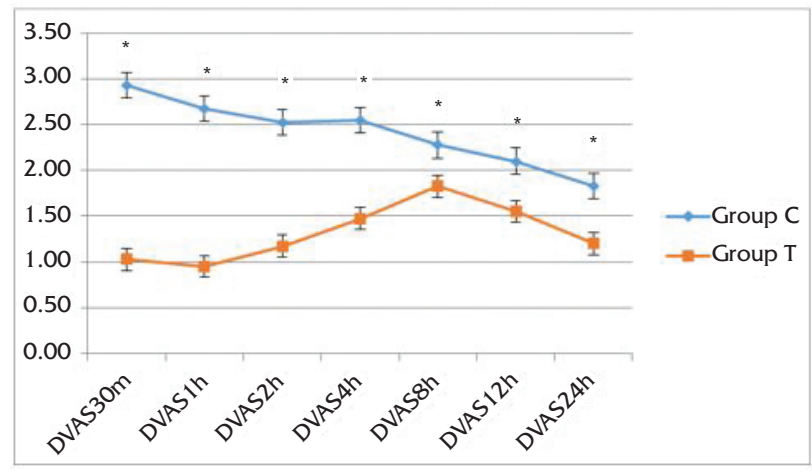

DVAS: Dynamic visual analog scale, Group C: General anesthesia

Group T: General anesthesia + Thoracolumbar interfascial plane block

*Statistically significant difference $(p<0.05)$.

Figure 2. Dynamic visual analog scale scores over $24 \mathrm{~h}$ after surgery.

\section{DISCUSSION}

TLIP is an interfascial plane block first described by Hand et al. ${ }^{4}$ for postoperative pain control following lumbar region surgeries. This block was redefined as the lateral TLIP block by Ueshima et al. ${ }^{5}$ using a different technique. In this novel technique, the effectiveness of postoperative analgesia is the same as that achieved in the first TLIP method described, although the infection rate is lower. This is due to the local anesthetic injection being closer to the surgical site in the first technique described ${ }^{9}$. In their retrospective 175 case series study involving the two described TLIP blocks, Ueshima et al. ${ }^{10}$ stated that the risk of complications was lower, and that the technique was safer in the modified TLIP. Xu et al. ${ }^{11}$ reported in their three-case study that the modified TLIP block can be safely and easily employed for postoperative analgesia in lumbar region surgeries. We also employed the modified lateral
TLIP block, described as an alternative to the first block technique, in the present study. The number of previous studies involving the modified TLIP block is quite limited. We used the QoR-40 quality of recovery inventory together with 24-h VAS scores in order to assess quality of recovery after anesthesia and patients' early postoperative state. Any studies concerning the postoperative analgesia method used for these surgical procedures have not been performed so far.

Ammar et al. ${ }^{12}$ used bilateral $20 \mathrm{ml}(10 \mathrm{ml} \% 0.25$ bupivacaine and $10 \mathrm{ml} \% 1$ lidocaine) injection fluid in their single or multilevel lumbar disk operations and reported that the firstly described TLIP block was a safe and effective method for postoperative analgesia following lumbar discectomy. Ueshima et al. ${ }^{13}$ investigated the firstly described TLIP block by using $40 \mathrm{~mL}$ 0.375\% levobupivacaine (20 $\mathrm{mL}$ to each side) in single-or multilevel lumbar disk operations and reported that this provided effective perioperative analgesia. As in the present research, in both of these studies static and dynamic VAS scores were recorded. The VAS scores obtained in the present research correlated exactly with the scores reported from those two earlier studies.

Ahiskalioglu et al. ${ }^{8}$ applied the modified TLIP block using $40 \mathrm{~mL} 0.25 \%$ bupivacaine $(20 \mathrm{~mL}$ to each side) in their multilevel lumbar instrumentation surgeries and observed a statistically significant difference in $24 \mathrm{~h}$ static and dynamic VAS scores at all time points, in postoperative fentanyl consumption, and in the numbers of patients using rescue analgesia. The authors concluded that the modified TLIP block may represent an important component of multimodal analgesia in vertebral surgery. We also used $40 \mathrm{~mL} 0.25$ bupivacaine in the present study ( $20 \mathrm{~mL}$ to each side). Similarly, we also observed VAS scores for $24 \mathrm{~h}$ and determined statistically significant differences between the groups in both static and dynamic VAS values with the exception of static VAS at 8 . and 12 . hrs. Significant differences were also observed be- 
tween the groups in terms of postoperative fentanyl consumption and numbers of patients using rescue analgesia, in agreement with the results of Ahiskalioglu et al.'s study.

In their two-case study involving the modified TLIP block with $40 \mathrm{~mL} 0.375 \%$ ropivacaine (20 $\mathrm{mL}$ to each side) in multilevel lumbar disk surgeries, Li et al. ${ }^{14}$ showed an effective reduction in static pain over $48 \mathrm{~h}$, and in dynamic pain over 24 $h$ postoperatively. These findings are also consistent with the present study.

The QoR-40 quality of recovery inventory has recently started to be used to assess quality of early postoperative recovery in numerous studies. While different surgical and anesthetic techniques have been employed, the effectiveness of the analgesia method employed has been evaluated with QoR-40 quality of recovery inventory ${ }^{15,16}$. We also employed QoR-40 together with VAS scores, postoperative fentanyl consumption, and numbers of patients using rescue analgesia. The QoR-40 quality of recovery subdimensions of emotional state, physical comfort, psychological support, physical independence, and pain results were all significantly in favor of patients undergoing the modified TLIP block.

\section{CONCLUSION}

Patients undergoing the modified TLIP block had lower postoperative fentanyl requirements, less pain for $24 \mathrm{~h}$ after surgery, and better quality of recovery scores. We think that the modified TLIP block may represent an important stage in analgesia for lumbar spinal surgery.

\section{REFERENCES}

1. Memtsoudis SG, Vougioukas VI, Ma Y, Gaber-Baylis LK, Girardi FP. Perioperative morbidity and mortality after anterior, posterior, and anterior/posterior spine fusion surgery. Spine (Phila Pa 1976). 2011;36:1867-77. [CrossRef]
2. Tan M, Law LS, Gan TJ. Optimizing pain management to facilitate enhanced recovery after surgery pathways. Can J Anaesth. 2015;62:203-18. [CrossRef]

3. Chin KJ, McDonnell JG, Carvalho B, Sharkey A, Pawa A, Gadsden J. Essentials of our current understanding: Abdominal wall blocks. Reg Anesth Pain Med. 2017;42:13383. [CrossRef]

4. Hand WR, Taylor JM, Harvey NR, et al. Thoracolumbar interfascial plane (TLIP) block: a pilot study in volunteers. Can J Anaesth. 2015;62:1196-200. [CrossRef]

5. Ueshima $\mathrm{H}$, Otake $\mathrm{H}$. Clinical experiences of ultrasoundguided lateral thoracolumbar Interfascial plane (TLIP) block. J Clin Anesth. 2017;39:145. [CrossRef]

6. Myles PS, Weitkamp B, Jones K, Melick J, Hensen S. Validity and relibility of a postoperative quality of recovery score: the QoR-40. Br J Anaesth. 2000;84:11-5. [CrossRef]

7. Karaman S, Arici S, Dogru S, Karaman T, Tapar H, Kaya Z, Suren M, Gurler Balta M. Validation of the Turkish version of the Quality of Recovery-40 questionnaire. Health Qual Life Outcomes. 2014;12:8. [CrossRef]

8. Ahiskalioglu A, Yayik AM, Doymus O, et al. Efficacy of ultrasound-guided modified thoracolumbar interfascial plane block for postoperative analgesia after spinal surgery: a randomized-controlled trial. Can J Anaesth. 2018;65:603-4. [CrossRef]

9. Ueshima $\mathrm{H}$, Otake $\mathrm{H}$. Clinical experiences of ultrasoundguided lateral thoracolumbar Interfascial plane (TLIP) block. J Clin Anesth. 2017;39:145. [CrossRef]

10. Ueshima $H$, Otake $H$. Ultrasound-guided thoracolumbar interfascial plane block: Complications in 175 consecutive cases. J Clin Anesth. 2019;58:5-6. [CrossRef]

11. Xu JL, Doherty T, Patel R, Galeno J, Dotzauer B. Analgesic efficacy of ultrasound-guided modified thoracolumbar interfascial plane block performed with the use of neurophysiology monitoring for postoperative lumbar surgery. J Clin Anesth. 2019;52:21-23. [CrossRef]

12. Ammar MA, Taeimah M. Evaluation of thoracolumbar interfascial plane block for postoperative analgesia after herniated lumbar disc surgery: A randomized clinical trial. Saudi J Anaesth. 2018;12:559-564. [CrossRef]

13. Ueshima $H$, Hara E, Otake $H$. Thoracolumbar interfascial plane block provides effective perioperative pain relief for patients undergoing lumbar spinal surgery; a prospective, randomized and double blinded trial. J Clin Anesth. 2019;58:12-17. [CrossRef]

14. Li C, Jia J, Qin Z, Tang Z. The use of ultrasound-guided modified thoracolumbar interfascial plane (TLIP) block for multi-level lumbar spinal surgery. J Clin Anesth. 2018;46:49-51. [CrossRef]

15. Mathew P, Aggarwal N, Kumari K, et al. Quality of recovery and analgesia after total abdominal hysterectomy under general anesthesia: A randomized controlled trial of TAP block vs epidural analgesia vs parenteral medications. J Anaesthesiol Clin Pharmacol. 2019;35:170-5. [CrossRef]

16. Fujimoto $\mathrm{H}$, Irie $\mathrm{T}$, Mihara $\mathrm{T}$, Mizuno $\mathrm{Y}$, Nomura T, Goto T. Effect of posterior quadratus lumborum blockade on the quality of recovery after major gynaecological laparoscopic surgery: A randomized controlled trial. Anaesth Intensive Care. 2019;47:146-151. [CrossRef] 